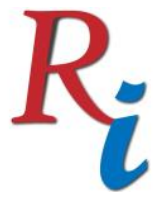

Asia Proceedings of Social Sciences

(APSS)

www.readersinsight.net/APSS

\title{
THE INFLUENCE OF PRODUCTION FACTORS TOWARD ECONOMIC GROWTH IN INDONESIA \\ Wilson Bangun*
}

Economics Faculty

Maranatha Christian University

Indonesia

*Corrosponding author's Email: wilson.bangun@yahoo.co.id

Author's Biography

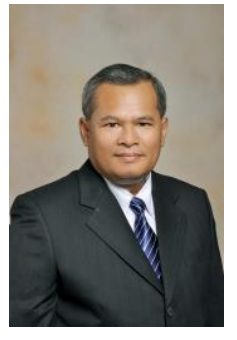

Prof. Dr. Wilson Bangun, affiliation at the Economics Faculty, Maranatha Christian University, a concentration of Human Resource Management and Organizational Behavior. Lectures on the subjects of Human Resource Management, Organizational Behavior, Microeconomic Theory, Industrial Relations, and Business Research Methods in several universities in Indonesia. The books that have been published: Teori Mikro Ekonomi. Bandung: Refika Aditama, 2007; Intisari Manajemen Refika Aditama, Bandung: 2008; Manajemen Sumber Daya Manusia, Jakarta: Erlangga, 2012; Manajemen SDM: Hubungan Industrial, Erlangga, Jakarta: 2017. Other scientific articles published in national and international journals. Also as a speaker at national and international conferences in various countries.

Peer-review under responsibility of $3^{\text {rd }}$ Asia International Multidisciplanry Conference 2019 editorial board (http://www.utm.my/asia/our-team/) (C) 2019 Published by Readers Insight Publisher, lat 306 Savoy Residencia, Block 3 F11/1,44000 Islamabad. Pakistan, info@readersinsight.net This is an open access article under the CC BY-NC-ND license (http://creativecommons.org/licenses/by-nc-nd/4.0/). 


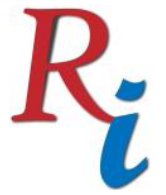

\section{Asia Proceedings of Social Sciences \\ (APSS) \\ www.readersinsight.net/APSS}

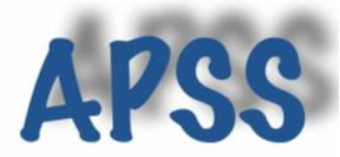

\section{Rese a r ch H i g h I igh t s}

Each countries in the world believe that economic growth is used as a measure to achieve the welfare of people. Therefore, every country seeks to manage economic resources efficiently and effectively to increase the economic growth. Based on Neo Classical theory, the production factors of capital and labor determine of Indonesia economic growth, while the contribution of technological progress is low. Indonesia technological developments are behind compared Singapore, Malaysia, Thailand, and the Philippines (Bangun, 2017). Population is an important factor in determining a countries economic development. However, for developing countries rapid population growth will be a challenge because of unpreparedness in savings as an investment. The role of the workforce is very important, both as workers and as managerial to increase output which results in increased income. But, the challenge for Indonesia is the workforce is still dominated by unskilled workforce, which cause results in low national income (Bangun, 2018).

\section{Research Objectives}

The factor of labor production provides the biggest contribution to Indonesia economic growth, but it has employee is low. While, influence of production factors the capital and technology toward economic growth are low. The aims of this research are to knowing the influence of production factors tward Indonesia economic growth.

\section{Methodology}

To knowing the magnitude of the influence of each production factor on Indonesia economic growth is done through the Neo Classic approach using the Cobb-Douglas production function with the Ordinary Least Square (OLS) estimation method. The general equation for Indonesia economic growth is formulated as follows:

$\ln \mathrm{Y}=\ln \mathrm{a}+\mathrm{bi} \sum_{i=1}^{3} X_{i}+\mathrm{e}$

where a is an intercept, bi is the regression coefficient that will be assumed, $\mathrm{Y}$ is Indonesia economic growth with the Gross Domestic Product (GDP) approach, X1 is capital with a total investment approach, there are Foreign Direct Iinvestment (FDI) and the domestict investment, $\mathrm{X} 2$ is labor, and X3 is Technology, and e are other factors that contribute to Indonesia economic growth. The data used is secondary data: Factors of production of capital are the data of progressing of FDI and domestic investment (government and private investment) in Indonesia using data from the World Bank, 2004-2016; Employment is the data of progressing of the Indonesian workforce, 2004-2016 sourced from the Biro Pusat Statistik Republik Indonesia.

\section{Results}

Based on the statistical output, the multiple regression equation is as follows:

$\mathrm{Y}=-323,291+33,681 \mathrm{X} 1-11,274 \mathrm{X} 2$

Then each factor of production is analyzed dynamically so that Indonesian economic growth will be obtained equation follow:

$\mathrm{rY}=\mathrm{r} X_{3}+33,681 \mathrm{r} X_{1}-11,274 \mathrm{r} X_{2}$

$11,65 \%=\mathrm{r} X_{3}+33,681(1,61 \%)-11,274(2,72 \%)$

$\mathrm{r} X_{3}=-12,15 \%$.

The results of statistical analysis show that Indonesia economic growth is determined by factors of labor production and capital positively. While the technology production factor is negative at $-12.15 \%$. At this level of economic growth, the growth of Indonesian labor is $1.61 \%$ and 


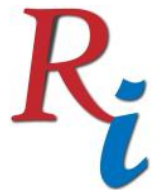

\section{Asia Proceedings of Social Sciences \\ (APSS) \\ www.readersinsight.net/APSS}

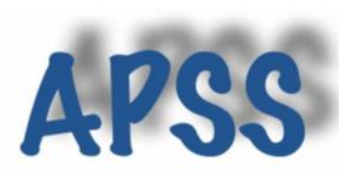

capital growth is $2.72 \%$. Capital is a factor of production that is used both directly and indirectly in production activities to increase economic growth. Capital is a portion of income saved for reinvestment with the aim of increasing future income. Capital in increasing a countries economic growth is domestic investment and foreign investment. Technology is a production factor that functions to convert raw materials into products that have higher economic value.

\section{Findings}

The findings of this study indicate that there are significant effects of production factors on Indonesia economic growth. The factor of labor production has a major influence on Indonesia economic growth, but it must also increase the number of FDI and technology. The phenomenon of income inequality is caused by differences in technological advances between countries and is an asymmetric impact of globalization of world trade and financial markets (Wijoyo Santoso. 2012). Capital in increasing a countries economic growth is domestic investment and FDI. Some studies show that FDI will increase work productivity (Liu, et al., 2000).

\section{Acknowledgement}

This article was presented at the 3rd Asia International Multidiciplinary Conference organized by Asia Connecting and Universiti Teknologi Malaysia in Johor, Malaysia on 1-2 May 2019. Thanks a lot to the Maranatha Christian University for supporting facilities and funds in completing this research and documentation in attending this conference. Highest gratitude to my parents: Rahman Bangun and Basita Sitepu. Likewise, thanks to my wife and sons, Nita Sitepu, Christian Deswinta Bangun and Soni Eduardo Bangun who supported the prayer in my achievements as a lecturer.

\section{References}

Bangun, W. (2017). "Labor Productivity and Competitiveness (A Study: The Comparison of Indonesian With ASEAN)." International Journal of Applied Business and Economics Research 14(11): 289-294.

Bangun, W. (2018). The Quality of Human Resources: A Study of Indonesian on the ASEAN Economic Community. Proceeding of The 2nd International Conference on Family Business \& Entrepreneusship., President University.

Bank, W. (2015). from http://data.worldbank.org/.

B. P. S. R. I. (2004-2016). Biro Pusat Statistik Republik Indonesia.

Liu, Siler, Wang, Wei. (2000). "Productivity spillovers from Foreign direct investment: evidence from UK industrylevel panel data." Journal of International Business Studies 31: 407-425.

Santoso, W. (2012). Outlook Ekonomi Indonesia 2008-2012: Integrasi Ekonomi ASEAN dan Prospek Perekonomian Nasional, Bank Indonesia: Biro Riset Ekonomi Direktorat Riset Ekonomi dan Kebijakan Moneter. 